The Journal of Engineering and Exact Sciences - JCEC, Vol. 04 N. 04 (2018)

journal homepage: https://jcec.ufv.br

doi: https://doi.org/10.18540/jcecvl4iss4pp0383-0389

OPEN ACCESS - ISSN: 2527-1075

\title{
THE COMPETENCES DEVELOPED BY THE PETROLEUM SEGMENT EQUIPMENT INSPECTION ENGINEER
}

\section{AS COMPETÊNCIAS DESENVOLVIDAS PELO ENGENHEIRO DE INSPEÇÃO DE EQUIPAMENTOS DO SEGMENTO DE PETRÓLEO}

\section{J. A. P. NICÁCIO ${ }^{1, *}$ and A. M. TONINI ${ }^{2}$}

${ }^{1}$ Federal Center of Technological Education of Minas Gerais, Department of Technological Education, Belo Horizonte, Minas Gerais, Brazil and Petrobras, Gabriel Passos Oil Refinery, Department of Inspection, Betim, Minas Gerais, Brazil ${ }^{2}$ Federal Center of Technological Education of Minas Gerais, Department of Technological Education, Belo Horizonte, Minas Gerais, Brazil and Director of Engineering, Exact, Human and Social Sciences of the National Council of Scientific and Technological Development (CNPq), Brasília, Brazil

${ }^{*}$ Corresponding author. Petrobras, Department of Inspection, Gabriel Passos Oil Refinery, Betim, Minas Gerais, Brazil, Phone: +553135295176

e-mail addressl: jancler@petrobras.com.br (J.A.P. Nicácio).

\begin{tabular}{|c|}
\hline A R T I CLE INFO \\
\hline $\begin{array}{l}\text { Article history: } \\
\text { Received 2018-08-12 } \\
\text { Accepted 2018-09-28 } \\
\text { Available online 2018-10-31 }\end{array}$ \\
\hline $\begin{array}{l}\text { pa lavras-chave } \\
\text { Competências } \\
\text { Engenharia } \\
\text { Inspeção de Equipamentos } \\
\text { Petróleo }\end{array}$ \\
\hline $\begin{array}{l}\text { keywords} \\
\text { Competences } \\
\text { Enginnering } \\
\text { Inspection of Equipment } \\
\text { Oil }\end{array}$ \\
\hline
\end{tabular}

\begin{abstract}
A B S T R A C T
The equipment inspection engineer is responsible for the monitoring, control and maintenance of the integrity, as well as the extension of useful life of the equipment in service of process units of the most varied productive segments such as chemical, petrochemical, oil and gas. The way in which the professional career of the engineers is conducted presents several possibilities of discussion in the scope of Technological Education, one of these is the analysis of the training courses of the Corporate Universities. The Corporate University is development system based on the management of by skills, and provides for the development of business and human skills considered critical for the viability of business strategies. This paper proposes a discussion about the competencies developed by the professional engineers of equipment inspection that operate in the oil industry segment.
\end{abstract}

RES UM O/R ES U M EN

$O$ engenheiro de inspeção de equipamentos é responsável pelo monitoramento, controle e manutenção da integridade, bem como a extensão de vida dos equipamentos em serviço de unidades de processo dos mais variados segmentos como as indústrias químicas, petroquímicas, petróleo e gás. $O$ modo como se conduz a carreira profissional dos engenheiros apresenta diversas possibilidades de discussão no âmbito da Educação Tecnológica, uma dessas é a análise dos cursos de formação das Universidades Corporativas. A Universidade Corporativa é um sistema de desenvolvimento pautado pela gestão de pessoas por competências, e prevê o desenvolvimento das competências consideradas críticas para a viabilização das estratégias de negócio. Este trabalho propõe uma discussão sobre as competências desenvolvidas pelos engenheiros de inspeção de equipamentos que atuam no segmento da indústria do petróleo. 


\section{INTRODUCTION}

This paper is part of the research processes in Technological Education research line of the Post-Graduate Program of the Master's Degree in Technological Education of the Federal Center of Technological Education of Minas Gerais - CEFET/MG; which includes the research group Training and Professional Qualification (FORQUAP).

The oil sector today has a leading role in the world's energy supply - and will continue to be relevant in the long run. Currently, about $80 \%$ of the world's primary energy is supplied by fossil fuels - including coal $(52.5 \%$ for oil and gas). With the introduction of new renewable technologies in the global energy matrix, estimates indicate that this percentage will decrease over time but indicate that the oil and gas sector will continue to supply a significant part (50\% by 2040) of the world INTERNATIONAL ENERGY AGENCY (2016).

According to data from the IBP (2017), the momentum of the oil industry in Brazil and in the world is transitional. changes already announced a few years ago have accelerated dramatically. The collapse of oil prices at the end of the last commodity cycle has brought about a profound reconfiguration of the industry in search of competitiveness and profitability lost in the face of the expectation that prices will remain low for a long time.

The training, qualification and professional performance of the contemporary engineer require professionals capable of transposing the condition of engineers with only technical training. Therefore, in addition to this training, a professional profile is required to face the challenges and problems that the Engineering profession exposes, to propose solutions that consider not only the technically correct ones, but those that can contribute to the more democratic and social development. and that also contemplate the sustainability of Engineering activities for the safety, comfort and health of human beings according to Tonini (2007).

In this sense, according to Fleury (2013), engineers with general and specific skills, as well as excellent behaviors that add value, are often demanded by organizations. For the field of engineering is presented as fertile and promising, both for technological innovations and for the progress and development of organizations.

This new context of increasing complexity, uncertainty and volatility, whose main fuel will be innovation, finds Brazil beginning possibly one of the most profound transformations in the history of its oil, gas and biofuels industry. Currently, the petroleum industry requires professionals with technical training to act not only as managers of technology, but also as administrative managers in the broader scope of the term.

Today engineers need to understand the workings of the dynamic and complex system that characterizes a modern enterprise, coupled with the complex changes discussed above, addressing jobs that involve legal, financial, and economic issues related to the management of the people involved in the processes.

\section{JUSTIFICATION}

Technological advancement, disputes over new markets and globalization affected labor market characteristics, changing the demand of professionals, combined with changes in the way of production and new social requirements that reinforced the need for a new profile of the engineering professional, making this need for changes a recurrent subject in the academic world, in Brazil and abroad, according to Carvalho (2014).

Vocational training policies aim at the worker to develop the skills to apply scientific knowledge in all areas, making them capable of problematizing them, solving questions of social and productive practice, life in society and work. Thus, teaching models are established that, according to contemporary needs, allow, among other contents, the future professional to be able to handle, apply and develop technology.

Although there is a huge tradition in engineering, it should be noted that most of the professional skills desired for an engineer in recent years are far from the traditional profile developed over the last century.

Vocational training policies aim at the worker to develop skills to apply scientific knowledge in all areas, to be able to problematize them, to solve social and productive practice, life in society and work.

In the 1990, the debate about the profile of the engineer for the new millennium intensified, the term "competence" came to play a prominent role in the studies on the profile of the contemporary engineer and, according to Lucena et al. (2008) in Europe and in the United States of North America, important studies were begun to define what the necessary skills would be for the engineer.

Thus, it is not difficult to see that traditional training models are not able to provide and develop skills that have emerged in the last two decades, showing an urgent need for the search for new models for engineering training according to Tonini et al. (2012).

Thus, it is important to identify the relationships in the work situation of professional engineers regarding their training, qualification and professional performance in relation to new organizational and management technologies with possible repercussion for the training of these professionals in schools, institutes and engineering centers. At this point, the training of engineers by the organizations themselves

Within this scenario is the professional "equipment inspection engineer". Being able to look after the physical condition and the structural and operational integrity of several types of assets, such as: static equipment (pressure vessels, boilers, heat exchangers, process towers, furnaces, pipelines, pipelines, tanks and spheres) respecting the safe operation and environment conditions. 
In this sense, according to Fleury (2013), engineers with general and specific skills and who add value are highly demanded by organizations, as the field of engineering is a fertile and promising field for both technological innovations and progress and development of society. Every profession presents different challenges and requires different skills. Engineering is no different, with its challenges and requirements, regardless of its field of engineering, some skills are essential to the professional success of the engineer.

Thus, this paper is intended to contribute to the understanding regarding the competencies of professional engineers to inspect equipment that operate in the oil segment of a company operating in the Brazilian and international market.

Although there is a huge tradition in engineering, it should be noted that most of the professional skills desired for an engineer in recent years are far from the traditional profile developed over the last century. Thus, it is not difficult to see that traditional training models are not able to provide and develop skills that have emerged in the last two decades, showing an urgent need to search for new models for engineering training according to TONINI et al. (2012).

Thus, it is important to identify the relationships in the work situation of professional engineers regarding their training, qualification and professional performance in relation to new organizational and management technologies with possible repercussion for the training of these professionals in schools, institutes and engineering centers. This also includes the training of engineers by the organizations themselves.

\section{METHODOLOGY}

It can be said that methodology is the detailed and exact explanation of any action developed in the (path) of the research work. It is the explanation of the type of research, the instruments used (questionnaire, interview, etc.), the expected time, the team of researchers and the division of labor, tabulation and data processing, used in the research work.

It is the fundamental step of the research to explain the methodology adopted as a guideline for the steps to be taken in order to achieve the proposed objectives. It should be emphasized that the choice of the methodology to be followed is not random, according to Cervo and Bervian (1983) "The method is not invented, it depends on the object of the research".

Regarding the nature of the data and to reach the objectives of this research, the methodology was adopted with a qualitative approach. This was initially done through the collection of data through interviews with the following professionals: equipment inspection engineers, who participated in the training course in inspection engineering of a corporate university in the petroleum segment and that work in oil refineries.

\section{COMPETENCES}

The debate about competence was born precisely from the questioning of the concept of qualification and the process of professional training, mainly technical. Unhappy with the mismatch between the needs of the world of work (especially industry), they sought to bring education closer to the real needs of companies and organizations, in order to increase the skills of workers and their chances of employment.

The aim was to establish the relationship between skills and knowledge - know-how - in the framework of the diploma and employment. From the field of education, the concept of competence moved to other areas, such as the field of labor relations, in order to assess the skills needed for the job, thus creating an inventory of skills.

The growing use of the notion of "competence" in the Brazilian business environment has renewed interest in this concept. Be it from a more strategic perspective (organizational competencies, core competencies), or under a more specific configuration of practices associated with people management (selection, development, evaluation and compensation by competencies). The notion of competence has appeared as an important reference among management principles and practices in Brazil.

However, according to Ruas (2002): "Far from constituting a homogeneous universe, what is perceived is that the notion of competence presents many undefinitions". The professional competency model first emerged during the economic crisis of the 1970s, where the criteria related to the subjects were: responsibility, autonomy and training requirement, but what this classification classified was jobs and not people. Thus, "individuals were classified according to the occupation they occupy" according to Zarifian (2003).

The criteria of autonomy and responsibility, even going through the employment balance, are extremely important due to the paradigm break of the Taylorist tradition. Implicitly, competence was announced with reference to autonomy, giving the individual the opportunity to assert himself as subject. In this way, the role of individuality and the capacity for judgment emerges. With economic recovery in the mid-1980s, competence appears explicitly, and means: "delegating a portion of decisionmaking power to grassroots teams so that they can respond to increased performance complexity" according to Zarifian (2003). In the last two decades, especially in the previous one, the notion of competence has progressively occupied the debate in the sociological literature and in the "factory floor". It was posed by entrepreneurs, employers, translating concern about the new demands of the jobs and raising many questions according to Laudares and Tomasi (2003).

The debate about competence was born precisely from the questioning of the concept of qualification and the process of professional training, mainly technical. Unhappy with the gap between the needs of the world of work, they sought to bring education closer to the real needs of enterprises, with a view to increasing the skills of workers and their chances of employment. Competence is not limited to a stock of theoretical and empirical knowledge held by the professional, nor is it encapsulated in the task. According to 
Zarifian (1999) "Competence is practical intelligence for situations that rely on acquired knowledge and transform it with more force, the more the complexity of situations increases."

This classification proposed by Zarifian (1999) illuminates the formation of competences more directly related to the work process of industrial operations. According to this approach, the organization, located in an institutional environment, defines its strategy and the necessary competences to implement them, in a process of permanent learning. There is no order of precedence in this process, but rather a virtuous circle in which one feeds the other through the learning process.

The notion of competence is thus associated with verbs such as: knowing how to act, mobilizing resources, integrating multiple and complex knowledge, knowing how to learn, knowing how to engage, taking responsibility, having a strategic vision. Regarding the organization, skills should add economic value to the organization and social value to the individual.

In this way, the work is no longer the set of tasks associated with the position, but becomes the direct extension of the competence that the individual mobilizes in the face of an increasingly changing and complex professional situation. Competence is not limited to a stock of theoretical and empirical knowledge held by the professional, nor is it encapsulated in the task.

Le Boterf (1995) situates competence at a crossroads, with three axes formed by the person, his educational background and his professional experience. The notion of competence is thus associated with verbs such as: knowing how to act, mobilizing resources, integrating multiple and complex knowledge, knowing how to learn, knowing how to engage, taking responsibility, having a strategic vision. On the organizational side, skills must add economic value to the organization and social value to the individual. The same author defines competence as a responsible and recognized responsible knowledge, which implies mobilizing, integrating, transferring knowledge, resources and skills, which add economic value to the organization and social value to the individual.

Responsibility in the process of training the engineer and his role in the participation in the production system are important vectors to be observed during the process of training a creative subject and, at the same time, conscious in the search for solutions to the problems of engineering. Also, according to Tonini and Dutra (2009), the concern with the teaching of engineering permeates debates in this sense, the construction of the technical capacity of engineers is currently recognized as an important priority for the community of engineers, educational institutions and society as a whole. According to Tonini (2009), in general, the required skills of engineers are related to technical knowledge, teamwork and multidisciplinary, initiative, action with awareness of the impacts of their actions in the production chain and in society, and learning constant (continuing education).

Responsibility in the process of training the engineer and his role in the participation in the production system are important vectors to be observed during the process of training a creative subject and, at the same time, conscious in the search for solutions to the problems of engineering.

\section{WORK AND EDUCATION}

According to Pochmann (2012) "The main historical transformations in the process of formation for human labor are associated with the ways in which societies have managed to organize themselves for the generation and distribution of wealth."

The world that emerges at the beginning of the 21st century is more productive and wealth-generating on a scale well above the needs of global human service, putting the unparalleled opportunity for building a society at the top, especially in the advanced economies.

In general, the evolution of societies has allowed man to gradually free himself from Labor bound only by the strict necessity of survival according to MASI (1999). In agrarian societies, for example, work turned fundamentally towards the strict objective of providing survival, requiring that its exercise should occur from the infancy stage to the terminal aging.

According to Castro (2010), the relationship between work and education was closer since the 1960s due to the emergence of human capital theory, making education of great importance for economic development because it enhances work, qualifying the labor force. To better understand what work means, according to Saviani (1996) defined it as "the act of acting upon nature, adapting it to human needs." From this definition, it is possible to perceive the work as human essence. Showing that for man to continue to exist, he needs to produce his own existence by his work, making his life determined by the way his existence is produced.

The qualification thus understood expresses relations of power within productive processes and in society; it also implies recognition that schooling and vocational training are necessary but insufficient conditions for social development.

This is because it is known that only concrete policies and actions that allow real social and economic development (income distribution, agrarian reform, health system reform and education) may be overcoming inequalities and building social conditions that lead to citizenship.

Still according to Castro (2010), in the communal mode of production, which is called primitive communism, people were educated at the same time that they worked with each other, cultivating the land, being linked education and labor. When these people came to dominate the land, surplus and private property arise, dividing people into classes. There was a group that needed to work to maintain and support the other group, which did not need to work because they had people who worked in their place, thus, an idle and differentiated class emerged according to Saviani (1996).

According to Castro (2010) with the emergence of capitalism, the relations between education and labor change, they cease to be natural to be social, through the social contract. Having the worker his freedom to sell his labor power to the owners of the means of production. And the school at this juncture becomes important for bourgeois society, because it appears as an agent linked to progress, to 
the needs of civilized habits, which correspond to life in society and the formation of the citizen. On this subject, according to Frigotto (2008) says that Education plays a fundamental role for the evolution of capitalism, promoting inequalities between nations and social groups. This materialization occurs through the professional education, inculcating in its customers that for them to get a job they need to become productive, adapted, trained and trained citizens.

In the 20th century, however, access to education gradually became widespread, reaching increasing portions of the urban-industrial society as a whole, with the universalization of access to the earliest age groups becoming a requirement of sociability and preparation for the exercise of job.

In the postindustrial society, education tends to follow more closely the long cycle of human life, not only as an element of entry and continuity in the exercise of heteronomous work, but also as a necessary condition for extended citizenship throughout life.

In this context, the school emerged so that these people, belonging to the idle and ruling class could attend to develop meaningful studies, with noble and dignified activities, learning polite attitudes and warlike activities. While the majority of the population continued to educate themselves through work, in the very process of producing their existence and the existence of their masters.

Thus, in order to meet the profile of this new Brazilian worker, educational spaces assume the responsibility of developing new pedagogical, organizational and management practices, evaluative, methodological and formative processes, in order to supply the demand for skilled labor for the market according to Groszevicz (2010) "Each new phase of the division of labor also determines the relations of individuals with each other, as regards the material, the instrument and the product of labor."

Brazilian education today presents several guiding guidelines for its development in its different levels of education. This is because, since the middle 1990, different measures have been created to meet the new demands arising from the political and economic sphere, which, in general, reinforce the redefinition of the State's role with regard to their performance in society. It can be verified that these measures meet the new demands arising from the dominant productive system that, in this context, starts to implement new strategies of organization and functioning, as a way of overcoming the crisis triggered in the 1970 .

\section{CORPORATE EDUCATION}

Education is a necessary instrument for the country's growing changes and development. If on the one hand its importance is unquestionable, for other, lack of investment in qualification and education of the workforce is one of the greatest obstacles to progress.

Education is a necessary instrument for the country's growing changes and development. If on the one hand its importance is unquestionable, on the other, the lack of investment in qualification and education of the workforce is one of the biggest obstacles found for progress. According to
Eboli (2013) the context of emergence and the dynamics of corporate universities are a topic that deserves to be discussed, since they have revolutionized the way people are trained in organizations, going far beyond the business environment, insofar as they also influence the educational systems and the production of knowledge within contemporary society.

Corporate education is justified, according to the literature, by the 'inability' of the state to provide adequate labor for the market. In this way, organizations call this responsibility, defending the displacement of the role of the state to the entrepreneurship in the direction of educational projects - Theory of Intellectual Capital. In other words, "companies ... instead of waiting for schools to make their curricula more relevant to business reality, they decided to go the other way and bring the school into the company" according to Meister (1999).

In an economic scenario where competition is increasingly competitive, it is necessary to acquire competitive advantages over other players in the market. One of the most effective ways to do this is to work on the company's commitment to the development of its employees.

The corporate university, in turn, emerged as a way to contribute to the formation and retention of professionals, where they develop, are educated and valued for this. Thus, it is shown as a response of the companies to the challenges of the professionals involved in their respective businesses.

Thus, educational programs that were restricted to managerial levels and to senior management are being expanded, encompassing with education all employees of the company. As seen so far, Corporate Education, also called Business Education, occurs when the organization establishes a strong learning process that has as a priority the acquisition, maintenance and dissemination of knowledge.

The phenomenon of universities created and maintained by companies is not so recent. A study by Quality Dynamics - a US consultancy firm found that in 1988 there were 400 such institutions in the United States. In 1999, the number of corporate universities grew to almost 2,000, according to Meister (1999). In this context, the teaching activities run by the companies promote a training program oriented to the objectives of the organization, guaranteeing a unified message and a common language

The concept of corporate education emerges at the end of the 20th century. In essence, there are five forces that sustained the emergence of this phenomenon: flexible (not hierarchical, responsive) organizations; the age of knowledge (knowledge economy); rapid obsolescence of knowledge; employability and education for global strategy according to Almeida (2014). The basic purpose of a corporate education system in an organization is to foster: "The development and installation of business and human skills considered critical to the viability of business strategies" in a systematic, strategic and continuous way according to Eboli (2004).

Leaders and employees need to recycle their knowledge and use continuous learning to improve the time spent on day-to-day tasks and achieve greater goals. To make this real, the first action is to understand that the company is not the sole holder of knowledge. It is necessary to identify 
potential employees and thus encourage them to seek more and more innovation and new content. Another point is to note that organizational models tend to become less and less formal, facilitating interaction and communication between people in between. This fact is already a reality for many companies today.

When corporate education in companies is carried out efficiently, there is a better result in decision making, faster task resolution on a daily basis and a potential improvement in internal communication. Depending on skills acquired by professionals, companies are running the risk of being left without what they need. Many institutions give their graduates to the labor market in a way that is not productive for the business routine. The mass of trainees has a lot of theory and little practice. There are also those who have a poor or outdated theory. These factors turn out to be losses of all kinds - from the shortage of qualified professionals to bad results for inexperienced or poorly trained young people.

At the present time, it is possible to notice that several companies have seen in corporate education an attractive solution and, to a greater or lesser degree, have started to provide specific training to their already hired professionals. At times to meet a shortage of external professionals, in others seeking to value the professionals themselves or achieve excellence in their area of expertise. This solution has been increasing in number of companies and the satisfaction of trained professionals.

Corporate education is a coordinated practice of people management integrated with knowledge management in which it is oriented to the long-term strategy of a company. In other words, corporate education is much more than a simple business training or job qualification offered by a company to its employees. In this case, it is a question of coherently articulating the individual and organizational competences in the broader context of the company. Therefore, corporate education practices are intrinsically related to the process of innovation in companies. And also to increase the competitiveness of your products or services. In this context, corporate education has been growing rapidly in Brazil.

The corporate university is an educational institution linked to public or private companies. Also known as business university, it can offer training to employees from technical or undergraduate courses at a higher level. The corporate university is considered as the field of activity of business pedagogy.

Thus, educational programs that were restricted to managerial levels and to senior management are being expanded, encompassing with education all employees of the company. Corporate education, or also called business education, occurs when the organization establishes a strong learning process that has as a priority the acquisition, maintenance and dissemination of knowledge. It should be noted that educational programs in companies have always existed, but usually they were restricted to managerial levels and top management. For the vast majority of employees there were occasional training programs. The emergence of corporate universities was the great milestone of the transition from the traditional "training and development center" to a broader and broader concern with the education of all employees of a company, and in practice, with its advent coming the new modality of corporate education.

\section{CONCLUSION}

The management of the work of the engineers diversifies according to the needs of each company surveyed. The demand for specific technical knowledge is understood in the investment in professional training that companies and professionals do. However, the need for training for an inspection career is normatively surrounded by a broad technical context. Which leads to interpret that this necessity should be attended by the professional formation of this engineer in a corporate university.

The analysis of the competencies developed by engineers working in the petroleum industry conducted in the present paper points to a pressing reflection to be made in the environment of a corporate university, in which the question of the training of its professionals should be based on the broad range of technical knowledge inherent to the scope of engineering for the acquisition of competences related to the interpersonal relationship, the ability to work in a team, and valorization of social and environmental responsibility.

Finally, the training and qualification of the engineer are no longer restricted to the undergraduate course for essentially technical training. The global factory is demanding a professional with flexible and expanded performance in the field of social relations of work in addition to technical performance, with capacity for upgrading qualification.

\section{ACKNOWLEDGMENT}

My thanks to the Federal Center for Technological Education of Minas Gerais and the entire faculty of the master's degree in Technological Education, in addition to the management and administration, who carry out their work with such love and dedication, working tirelessly so that we, students, can education. Thus, as well as the equipment inspection engineers and the faculty of the corporate university analyzed, my sincere thanks for the support given in carrying out this work.

\section{R E F E R E N C E S}

ALMEIDA, G. P. de. A aplicação de competências científicas no trabalho: um estudo preliminar no Banco do Brasil. Dissertação. Universidade Católica de Brasília. Brasília-DF. 2014.

CARVALHO, L. A. Competências requeridas na atuação profissional do engenheiro contemporâneo. Dissertação. Centro Federal de Educação Tecnológica de Minas Gerais - CEFET/MG. Programa de Mestrado em Educação Tecnológica. Belo Horizonte/MG. 2014.

CASTRO, J. N. A relação entre trabalho e educação no colégio técnico da universidade federal do Rio de Janeiro. Revista Digital. Buenos Aires, Ano 15, N ${ }^{\circ}$ 147, Agosto de 2010.

EBOLI, M. Educação corporativa no Brasil: Mitos e Verdades. 3 ed. São Paulo. Editora gente. 2004.

EBOLI, M.. Estratégias empresariais e formação de 
competências: um quebra-cabeça caleidoscópio da indústria brasileira. São Paulo: Atlas, 2013.

FLEURY, Afonso. Aprendizagem e Inovação Organizacional: as experiências de Japão, Coréia e Brasil. São Paulo: Atlas, 1995.

FRIGOTTO, G. Concepções e Mudanças no Mundo do Trabalho e o Ensino Médio. CEFET-BA, Bahia, 2008.

GROSZEVICZ, E. Concepções sobre a relação entre educação e trabalho. Anais do XIX EAIC - 28 a 30 de outubro de 2010, UNICENTRO, Guarapuava. 2010.

INSTITUTO BRASILEIRO DE PETRÓLEO, GÁS E BIOCOMBUSTÍVEIS. Agenda da indústria 2017. 35p. 2017.

INTERNATIONAL ENERGY AGENCY. Key World Energy Statistics. 2016.

LE BOTERF, G. De la compétence - essai sur um attracteur étrange. In: Les éditions d'organisations. Paris: Quatrième Tirage, 1995.

LUCENA, J. et al. Competencies beyond countries: the reorganization of engineering education in the United States, Europe and Latin America. Journal of Engineering Education, v. 97, n. 4, p. 433-447, 2008.

MASI, Domenico de. O futuro do Trabalho. Rio de Janeiro: Ed. José Olympio. 1999.

MEISTER, J. Educação corporativa: a gestão do capital intelectual através das universidades corporativas. São Paulo: Makron Books, 1999.

POCHMANN. Márcio. Trabalho e Formação: Temas multidisciplinares para a educação. Revista Educação e Realidade, v. 37, n. 2. Porto Alegre. mai./ago. 2012.

RUAS, R. L. Gestão das competências gerenciais e a aprendizagem nas organizações. Revista Administração. Porto Alegre: EA/PPGA/UFRGS, versão 2, 2002.

SAVIANI, D. O Trabalho como Princípio Educativo Frente às Novas Tecnologias. In: Novas Tecnologias, Trabalho e Educação: um debate multidisciplinar. Org. Ferretti, C. J. et al., Rio de Janeiro: Vozes, 1996.

SILVA. J. C.; TONINI, A. M. O desenvolvimento de competências na formação do engenheiro em projeto interdisciplinar no CEFET-MG. Belo Horizonte, VI SITRE. 2016.

TOMASI, A. P. N. Qualificação ou competência? In: TOMASI, A. (org.) Da qualificação a competência: pensando o século XXI. Campinas: Papirus, 2004.

TONINI, A. M. Novos tempos, novos rumos para a engenharia. Belo Horizonte: Revista da FUNDAC. Belo Horizonte, 2009.

ZARIFIAN, P. O modelo da competência. São Paulo: SENAC Editora, 2003. 